\title{
THE PYT'EV-CHULICHKOV METHOD FOR CONSTRUCTING A MEASUREMENT IN THE SHESTAKOV-SVIRIDYUK MODEL
}

\author{
M.A. Sagadeeva ${ }^{1}$, E.V. Bychkov ${ }^{1}$, O.N. Tsyplenkova ${ }^{1}$ \\ ${ }^{1}$ South Ural State University, Chelyabinsk, Russian Federation \\ E-mails: sagadeevama@susu.ru, bychkovev@susu.ru, tsyplenkovaon@susu.ru
}

\begin{abstract}
One of the approaches to solution of the problem on restoring a distorted input signal by the recorded output data of the sensor is the problem on optimal dynamic measurement, i.e. the Shestakov-Sviridyuk model. This model is the basis of the theory of optimal dynamic measurements and consists of the problem on minimizing the difference between the values of a virtual observation obtained using a computational model and experimental data, which are usually distorted by some noise. We consider the Shestakov-Sviridyuk model of optimal dynamic measurement in the presence of various types of noises. In the article, the main attention is paid to the preliminary stage of the study of the problem on optimal dynamic measurement. Namely, we consider the Pyt'ev-Chulichkov method of constructing observation data, i.e. transformation of the experimental data to make them free from noise in the form of "white noise" understood as the Nelson-Gliklikh derivative of the multidimensional Wiener process. In order to use this method, a priori information about the properties of the functions describing the observation is used.

Keywords: optimal dynamic measurement; Leontief type system; multidimensional Wiener process; Nelson-Gliklikh derivative; algorithm to solve the problem.
\end{abstract}

\section{Introduction}

One of the main problems of the theory of dynamic measurements is to find the influence on a measuring system by a signal that is recorded at the output of the system. The classical methods to solve this problem are methods based on the theory of inverse (ill-posed) problems (see the review [1]). Based on methods of the automatic control theory, A.L. Shestakov and his students proposed and substantiated technical hypotheses for solution of the problem on recovering a dynamically distorted signal [2]. Further studies showed that one of the ways to improve the accuracy of the results obtained when solving this problem is to study the mathematical model of the problem on recovering a dynamically distorted signal. To this end, A.L. Shestakov and G.A. Sviridyuk proposed to use methods of the theory of optimal control [3] by solutions of the system obtained as a result of using the theory of automatic control. The optimal dynamic measurement problem [4] is the obtained optimal control problem for a Leontief type system. Using the methods of numerical solutions for Leontief type systems [5], the constructed mathematical model was reduced "to the number" [6]. The reviews $[7,8]$ are devoted to description of this mathematical model. The resulting theory is called the theory of optimal dynamic measurements. In the theory of optimal dynamic measurements, noises of various types and natures can be taken into account. Therefore, to date, problems on optimal measurement were investigated in the presence of inertia of the measurement transducer (MT) [6], resonances in the MT circuits [9], as well as the MT degradation [10] understood as a decrease in the sensitivity of the MT when operation.

The theory of optimal dynamic measurements is based on the Shestakov-Sviridyuk model of description of the MT. This model consists of two parts. The first part of the 
Shestakov-Sviridyuk model is described using the nonstationary Leontief type system

$$
\begin{gathered}
L \dot{x}(t)=a(t) M x(t)+D u(t), \quad \operatorname{ker} L \neq\{0\}, \\
y(t)=b(t) N x(t)+F u(t),
\end{gathered}
$$

where $L, M, D, N, F$ are square matrices of the order $n, x(t)=\operatorname{col}\left(x_{1}(t), x_{2}(t), \ldots, x_{n}(t)\right)$, $y(t)=\operatorname{col}\left(y_{1}(t), y_{2}(t), \ldots, y_{n}(t)\right)$ and $u(t)=\operatorname{col}\left(u_{1}(t), u_{2}(t), \ldots, u_{n}(t)\right)$ are vector functions, $a(t)$ and $b(t)$ are functions. Here the matrices $L, M, D, N$ and $F$ characterize construction of the MT, the vector function $x=x(t)$ characterizes a state of the MT, the functions $a=a(t)$ and $b=b(t)$ describe degradation of the MT during longterm operation (for example, when operating in near-Earth space), the vector function $u=u(t)$ corresponds to the input signal (measurement), and the vector function $y=y(t)$ corresponds to the output signal (observation). In order to obtain the mathematical model of the MT, system (1), (2) is endowed with the initial Showalter-Sidorov condition [11]

$$
P\left(x(0)-x_{0}\right)=0,
$$

where $P$ is the orthogonal projection onto the image of the resolving family of matrices of homogeneous equation (1) [12]. The second part of the Shestakov-Sviridyuk model is the optimization problem

$$
J(v)=\min _{u \in \mathfrak{U}_{\partial}} J(u),
$$

which uses a functional of the form

$$
J(u)=J(u)=\varepsilon \int_{0}^{\tau}\|y(t)-\widetilde{y}(t)\|^{2} d t+(1-\varepsilon) \int_{0}^{\tau}\langle C x(t), x(t)\rangle d t
$$

to minimize the difference between the model observation $y$ and the observation $\widetilde{y}$ obtained as a result of processing the data of a natural experiment. Here $\|\cdot\|$ and $\langle\cdot, \cdot\rangle$ are the Euclidean norm and scalar product in $\mathbb{R}^{n}$. Using a priori information, a convex and closed subset $\mathfrak{U}_{\partial} \subset \mathfrak{U}$ called a set of admissible measurements is constructed. By minimizing the first term of functional (5) on the set $\mathfrak{U}_{\partial}$, we achieve the minimization of influence of the MT inertia on the measurement. And by minimizing the second term, we reduce influence of resonances in the MT circuits. (Note that a square symmetric matrix $C$ of the order $n$ characterizes the mutual influence of resonances in the MT circuits). The constant $\varepsilon \in(0,1)$ is chosen such that to take into account the preferences of the researcher. Finally, $\widetilde{y}(t)$ is an observation obtained as a result of a computational or natural experiment. Therefore, the problem on finding the optimal measurement $v(t)$ is to find minimum (4) of functional (5) for the vector functions $x$ and $y$ satisfying problem (1) - (3) for some initial data $x_{0} \in \mathbb{R}^{n}$. The Shestakov-Sviridyuk model can be represented by problem (1) - (5), which we also call the optimal dynamic measurement problem, and its solution allows to restore the signal $v \in \mathfrak{U}_{a d}$ corresponding to the observations $\widetilde{y}$.

In order to study Shestakov-Sviridyuk model (1) - (5), it is necessary to pay special attention to the methods of processing experimental data, with the help of which the deterministic function $\widetilde{y}$ is constructed. At the same time, when constructing the values of $\widetilde{y}$, various mathematical methods can be used to filter the data of a natural experiment, since the data are often distorted by random noise. On the one hand, the filtering methods 
for finding the useful part of the signal may not always be applicable, and on the other hand, such methods may give results that are not applicable for further investigation of the considered problem. The need to find the useful part of the signal arises in studies of various kinds (see, for example, $[2,13]$ ). As regards the theory of optimal dynamic measurements, in fact, this problem is a preliminary stage of the solution. On the basis of a priori information on the properties of functions describing the useful part of the observation, the Pyt'ev-Chulichkov method allows to construct the values $\widetilde{y}$ perturbed by "white noise", which is understood as the Nelson-Gliklikh derivative [14-16] of the $n$-dimensional Brownian motion.

The paper [17] describes the Pyt'ev-Chulichkov method in the one-dimensional case for optimal dynamic measurement problem. In this paper, our main purpose is to describe this method in the multidimensional case.

\section{Optimal Measurement Taking into Account Inertia, Resonances and Degradation of Measurement Transducer}

Let $L$ and $M$ be square matrices of the order $n, f(t)=\operatorname{col}\left(f_{1}(t), f_{2}(t), \ldots, f_{n}(t)\right)$ be some vector function. Linear inhomogeneous equations of the form

$$
L \dot{x}(t)=M x(t)+f(t), \quad \operatorname{det} L=0
$$

are called Leontief type equations, paying tribute to V. Leontief [18], who was the first to study such equations. Note that Leontief type equations are also called "differentialalgebraic equations" [19], "algebraic-differential systems" [20], "descriptor systems" [21], etc. As described above, the system of Leontief type equations of the form

$$
L \dot{x}(t)=a(t) M x(t)+D u(t)
$$

describes a part of the mathematical model of the MT, where $D, N, F$ are square matrices of the order $n, x(t)=\operatorname{col}\left(x_{1}(t), x_{2}(t), \ldots, x_{n}(t)\right), y(t)=\operatorname{col}\left(y_{1}(t), y_{2}(t), \ldots, y_{n}(t)\right)$ and $u(t)=\operatorname{col}\left(u_{1}(t), u_{2}(t), \ldots, u_{n}(t)\right)$ are vector functions, $a(t)$ and $b(t)$ are functions.

The matrix $M$ is said to be regular with respect to the matrix $L$ (in short, $L$-regular) if there exists a number $\alpha \in \mathbb{C}$ such that $\operatorname{det}(\alpha L-M) \neq 0$. It is clear that a number $\alpha \in \mathbb{C}$ such that $\operatorname{det}(\alpha L-M) \neq 0$ exists if $\operatorname{det} L \neq 0$. However, a careful analysis of real MT $[22,23]$ shows that the case $\operatorname{det} L=0$ takes place quite often. A matrix $M$ is called $(L, p)$-regular for $p$ equal to the order of the pole in $\infty$ for the function $(\mu L-M)^{-1}$. If infinity is a removable singular point of the $L$-resolvent of the matrix $M$, then $p=0$. For square matrices, the parameter $p$ cannot be more than the dimension of the space $n$.

Let the matrix $M$ be $(L, p)$-regular, $p \in\{0,1, \ldots, n-1\}$. Set the initial ShowalterSidorov condition [11]

$$
\left[R_{\mu}^{L}(M)\right]^{p+1}\left(x(t)-x_{0}\right)=0,
$$

where $R_{\mu}^{L}(M)=(\mu L-M)^{-1} L$ is the right L-resolvent of the matrix $M$, while $x_{0} \in \mathbb{R}^{n}$ is some vector. We fix the number $\tau \in \mathbb{R}_{+}$and consider the space of measurements

$$
\mathfrak{U}=\left\{u \in L_{2}\left((0, \tau) ; \mathbb{R}^{n}\right): u^{(p)} \in L_{2}\left((0, \tau) ; \mathbb{R}^{n}\right)\right\},
$$

the space of observations $\mathfrak{Y}=L_{2}\left((0, \tau) ; \mathbb{R}^{n}\right)$ and the space of states $\mathfrak{X}=\mathfrak{Y}$. 
Theorem 1. [8] Let the matrix $M$ be $(L, p)$-regular, $p \in\{0,1, \ldots, n\}$ and $\operatorname{det} M \neq 0$. Then for any $x_{0} \in \mathbb{R}^{n}, a \in C\left([0, \tau] ; \mathbb{R}_{+}\right) \cap C^{p}\left((0, \tau) ; \mathbb{R}_{+}\right), b \in C\left([0, \tau] ; \mathbb{R}_{+}\right)$and $u \in \mathfrak{U}$, there exists a unique solution $y \in \mathfrak{Y}$ to problem (1) - (3) given by (2) for unique solution of (6), (7) in the form

$$
x(t)=X(t, 0) x_{0}+\int_{0}^{t} X(t, s) L_{1}^{-1} Q D u(s) d s+\sum_{q=0}^{p} H^{q} M^{-1}\left(Q-\mathbb{I}_{n}\right)\left(\frac{1}{a(t)} \frac{d}{d t}\right)^{q} \frac{D u(t)}{a(t)} .
$$

Here $X(t, s)=\lim _{k \rightarrow \infty}\left(\left(L-\frac{1}{k} \int_{0}^{t} a(r) d r M\right)^{-1} L\right)^{k}$ is a degenerate flow [12], i.e. $X(t, r) X(r, s)=X(t, s)$ for all $t, r, s \in \mathbb{R}$ such that $t \geq r \geq s$, and $X(t, t) \neq \mathbb{I}_{n}$ for all $t \in \mathbb{R}$;

$$
\begin{gathered}
L_{1}^{-1}=\lim _{k \rightarrow \infty}\left(L-\frac{1}{k} M\right)^{-1} Q, \quad Q=\lim _{k \rightarrow \infty}\left(k L(k L-M)^{-1}\right)^{k}, \\
L_{0}=L\left(\mathbb{I}_{n}-P\right), \quad P=\lim _{k \rightarrow \infty}\left(k(k L-M)^{-1} L\right)^{k}, \quad H=M^{-1}\left(\mathbb{I}_{n}-Q\right) L_{0} .
\end{gathered}
$$

Remark 1. In Theorem 1, the condition $\operatorname{det} M \neq 0$ does not reduce the generality of the problem under consideration. Indeed, taking into account the $(L, p)$-regularity of the matrix $M$, the replacement $x=e^{\lambda t} r$ leads to the equation $L \dot{r}=(M-\lambda L) r+B u$, which is of the same form as the first equation of system (6), but with $\operatorname{det}(M-\lambda L) \neq 0$.

Let us formulate a theorem on the existence of a solution to optimal measurement problem (1) - (5).

Theorem 2. [8] Let the matrix $M$ be $(L, p)$-regular $(p \in\{0,1, \ldots, n\})$, $\operatorname{det} M \neq 0$. Then for any $x_{0} \in \mathbb{R}^{n}, \widetilde{y} \in \mathfrak{Y}, a \in C\left([0, \tau] ; \mathbb{R}_{+}\right) \cap C^{p}\left((0, \tau) ; \mathbb{R}_{+}\right)$and $b \in C\left([0, \tau] ; \mathbb{R}_{+}\right)$, there exists a unique measurement $v \in \mathfrak{U}_{\partial}$ for which (5) is satisfied.

\section{Multidimensional "White Noise"}

Let $\Omega \equiv(\Omega, \mathcal{A}, \mathbf{P})$ be a complete probability space, $\mathbb{R}$ be the set of real numbers endowed with Borel $\sigma$-algebra. A random variable is a measurable mapping $\xi: \Omega \rightarrow \mathbb{R}$. Random variables with zero expectation and finite variance form a Hilbert space $\mathbf{L}_{2}$ with the scalar product $\left(\xi_{1}, \xi_{2}\right)=\mathbf{E} \xi_{1} \xi_{2}$. Denote random variables $\xi \in \mathbf{L}_{2}$ that have normal (Gaussian) distribution by $\xi \sim N\left(0, \sigma^{2}\right)$, where $\mathbf{E} \xi=0$ and $\mathbf{D} \xi=\sigma^{2}$.

Let $\mathfrak{I} \subset \mathbb{R}$ be some interval. The mapping $\eta: \mathfrak{I} \times \Omega \rightarrow \mathbb{R}$ is called an (one-dimensional) stochastic process. For each fixed $t \in \mathfrak{I}$, the value of the stochastic process $\eta=\eta(t, \cdot)$ is a random variable, i.e. $\eta(t, \cdot) \in \mathbf{L}_{2}$, which is called a section of the stochastic process, and the value of the stochastic process $\eta=\eta(\cdot, \omega)$ is said to be a (sample) trajectory for each fixed $\omega \in \Omega$. A stochastic process $\eta$ is called continuous, if a.s. (almost sure) all its trajectories are continuous (that is, for a.a. (almost all) $\omega \in \Omega$, the trajectories $\eta(\cdot, \omega)$ are continuous). By a continuous Gaussian stochastic process we mean a continuous stochastic process whose (independent) sections are Gaussian.

The most important example of a continuous Gaussian stochastic process is the (onedimensional) Wiener process $\beta=\beta(t)$, which simulates Brownian motion on a straight 
line in the Einstein-Smoluchowski theory [24] and is represented by the formula

$$
\beta(t)=\sum_{k=0}^{\infty} \xi_{k} \sin \frac{\pi}{2}(2 k+1) t
$$

where $\xi_{k} \sim N\left(0,\left[\frac{\pi}{2}(2 k+1)\right]^{-2}\right)$ are independent normally distributed variables. The sections of the stochastic process $\beta$ are normally distributed random variables with $\mathbf{E} \beta(t)=0$ and $\mathbf{D} \beta(t)=\sigma^{2} t$ for some $\sigma>0$. The stochastic process $\beta$ represented by (8) is called one-dimensional Brownian motion.

We fix an arbitrary stochastic process $\eta=\eta(t)$ and the value of the parameter $t \in$ $\mathfrak{I}(=(\varepsilon, \tau) \subset \mathbb{R})$, and denote by $\mathcal{N}_{t}^{\eta}$ the $\sigma$-algebra generated by the random variable $\eta(t)$. Denote by $\mathbf{E}_{t}^{\eta}=\mathbf{E}\left(\cdot \mid \mathcal{N}_{t}^{\eta}\right)$ the conditional expectation with respect to the $\sigma$-algebra $\mathcal{N}_{t}^{\eta}$.

Let $\eta$ be a continuous stochastic process, then by the Nelson-Gliklikh derivative $\stackrel{\circ}{\eta}$ of the stochastic process $\eta$ at the point $t \in(\varepsilon, \tau)$ we mean a random variable

$$
\stackrel{\circ}{\eta}(t, \cdot)=\frac{1}{2}\left(\lim _{\triangle t \rightarrow 0+} \mathbf{E}_{t}^{\eta}\left(\frac{\eta(t+\Delta t, \cdot)-\eta(t, \cdot)}{\triangle t}\right)+\lim _{\triangle t \rightarrow 0+} \mathbf{E}_{t}^{\eta}\left(\frac{\eta(t, \cdot)-\eta(t-\Delta t, \cdot)}{\triangle t}\right)\right),
$$

if these limits exist. The stochastic process $\eta$ is called differentiable in the sense of NelsonGliklikh on $(\varepsilon, \tau)$, if there exists a Nelson-Gliklikh derivative at each point $t \in(\varepsilon, \tau)$.

Theorem 3. [15] Let $\beta$ be a Wiener process (8), then $\stackrel{\circ}{\beta}(t)=\frac{\beta(t)}{2 t} \quad \forall t \in \mathbb{R}_{+}$.

The sections of the stochastic process $\stackrel{\circ}{\beta}$ are normally distributed with the parameters $\left(0, \frac{\sigma^{2}}{4 t}\right)$, i.e. $\stackrel{\circ}{\beta}(t) \sim N\left(0, \frac{\sigma^{2}}{4 t}\right)$. Therefore, the Nelson-Gliklikh derivative $\stackrel{\circ}{\beta}$ of the Brownian motion $\beta$ from (8) is called an one-dimensional "white noise".

Let $n \in \mathbb{N}$. Consider $n$ independent random processes $\left\{\eta_{1}(t), \eta_{2}(t), \ldots, \eta_{n}(t)\right\}$ and define an $n$-dimensional random process (briefly, $n$-random process) by the formula $\Theta(t)=\sum_{j=1}^{n} \eta_{j}(t) e_{j}$, where $e_{j}$ are unit vectors in the space $\mathbb{R}^{n},(j=\overline{1, n})$. It is obvious that a.s. all its trajectories are continuous and differentiable in the sense of Nelson-Gliklikh, if $\eta_{j}(j=\overline{1, n})$ have these properties. By analogy with the one-dimensional case, by an n-dimensional (multidimensional) "white noise" we mean a stochastic process of the form $\stackrel{\circ}{W}_{n}(t)=\sum_{j=1}^{n} \stackrel{\circ}{\beta}_{j}(t) e_{j}$, where $\stackrel{\circ}{\beta}_{j}(t)$ is an one-dimensional "white noise" $(j=\overline{1, n})$.

\section{Pyt'ev-Chulichkov Method for Constructing Useful Part of Observation in the Presence of Multidimensional "White Noise"}

Suppose that, as a result of an experiment, we simultaneously observe several variables characterizing the observed process at equal intervals at time instants $\left\{t_{j}: j \in \mathcal{I}\right\}$, $\mathcal{I}=\{0,1, \ldots, N\}$, i.e. the observation is the $n$-dimensional vector $\left\{\eta^{1}(t), \eta^{2}(t), \ldots, \eta^{n}(t)\right\}$. As a result of such observations, we obtain $\eta^{i}\left(t_{j}\right)(i=\overline{1, n}, j=\overline{0, N})$. In addition, we know a priori information about the useful part of each observed variable $\eta^{i}(t)$, namely, 
about the extremum and the nature of convexity of the useful part. However, due to the influence of random noise, the observed variables $\left\{\eta^{i}\left(t_{j}\right)\right\}_{j=0}^{N}(i=\overline{1, n})$ do not have these properties. Assume that the observed variables can be represented as

$$
\eta(t)=\widetilde{y}(t)+\stackrel{\circ}{W_{n}}(t)
$$

where $\widetilde{y}:\left[t_{0} ; t_{N}\right] \rightarrow \mathbb{R}^{n}$ is the vector function of the useful part of the observation, and $\stackrel{\circ}{W}_{n}(t)$ is a part that involves noises at measurements, i.e. a multidimensional "white noise".

Since model of the MT (1), (2) is linear, it is clear that construction of observation values from the data distorted by the multidimensional "white noise" can be carried out for each coordinate separately. That is, each coordinate of the observation can be represented in the form

$$
\eta^{i}(t)=\widetilde{y}_{i}(t)+\stackrel{\circ}{\beta}_{i}(t) \quad(i=\overline{1, n}) .
$$

Here $\widetilde{y}_{i}(t)$ is the useful part corresponding to the $i$-th coordinate of the observation, and $\stackrel{\circ}{\beta}_{i}(t)$ is the part that involves noises at the corresponding coordinate, i.e. "white noise", the sections of which have the distribution given by $N\left(0, \frac{\sigma^{2}}{4 t}\right)$.

Let us briefly describe the statistical criterion for determining the position of the extremum point under the additional assumption of the uniqueness of the extremum point and the upward convexity of the useful part of the observation. To this end, we denote by $V_{k}$ the class of upward convex functions with the unique maximum at the point $t_{k}$ on the uniform grid $\left\{t_{j}: j \in \mathcal{I}\right\}, \mathcal{I}=\{0,1, \ldots, N\}$.

Fix the observation coordinate $i \in \mathbb{N}: 1 \leq i \leq n$. Suppose that the useful part of the signal $\widetilde{y}_{i}(t)$ has a maximum at the point $k_{0} \in \mathcal{I}$ of the uniform grid, i.e. $\widetilde{y}_{i} \in V_{k_{0}}$. Our goal is to estimate the parameter $k_{0}$ using the registered values $\left\{\eta^{i}\left(t_{j}\right)\right\}_{j=0}^{N}$, i.e., with a given probability $\gamma$, to estimate the parameter $k_{0}$ by the observation data:

$$
\eta^{i}(t)=\widetilde{y}_{i}(t)+\stackrel{\circ}{\beta}_{i}(t), \quad \widetilde{y}_{i} \in V_{k_{0}}, \quad \stackrel{\circ}{\beta}_{i}(t) \sim N\left(0, \frac{\sigma^{2}}{4 t}\right) .
$$

Based on the results obtained at [25], in order to estimate the parameter $k_{0} \in \mathcal{I}$ for the $i$-th coordinate of the observation, we use statistics of the form

$$
\tau_{k}(i)=\frac{\sum_{j=0}^{N}\left(\eta^{i}\left(t_{j}\right) \sqrt{t_{j}}-P_{k}\left(\eta^{i}\left(t_{j}\right) \sqrt{t_{j}}\right)\right)^{2}}{\sum_{j=0}^{N}\left(\overline{\eta^{i}}-P_{k}\left(\eta^{i}\left(t_{j}\right) \sqrt{t_{j}}\right)\right)^{2}},
$$

where $\overline{\eta^{i}}=\frac{1}{N+1} \sum_{j=0}^{N} \eta^{i}\left(t_{j}\right) \sqrt{t_{j}}$, and $P_{k}\left(\eta^{i}(t) \sqrt{t}\right)$ is the projection of $\eta^{i}(t) \sqrt{t}$ onto the set $V_{k}$, the existence of which is shown in [25] and the construction of which is described in [17]. The value of the constructed statistics is used to find the value of the parameter $k$ at which the useful part of the signal $\eta^{i}(t) \sqrt{t}$ is closest in the form to $P_{k}\left(\eta^{i}(t) \sqrt{t}\right)$.

Let us consider the problem on constructing the values of one coordinate of observations on a uniform grid $\left\{t_{j}\right\}_{j=0}^{N}$ as the problem on the best approximation of $\widetilde{y}_{i}(t) \sqrt{t}$ by elements of the set $V_{k}$, that is, search for the function $P_{k}\left(\eta^{i}(t) \sqrt{t}\right) \in V_{k}$ such that $\left\|P_{k}\left(\eta^{i}(t) \sqrt{t}\right)-\left(\eta^{i}(t) \sqrt{t}\right)\right\|^{2}=\inf _{f_{i} \in V_{k}}\left\|f_{i}-\eta^{i}(t) \sqrt{t}\right\|^{2}$. The work [17] presents the algorithm to construct the values of the useful part of one observation coordinate $P_{k}\left(\eta^{i}(t) \sqrt{t}\right)$. 


\section{Algorithm to Construct Useful Part of Observation}

Fig. 1 shows the algorithm to construct the useful part of one observation coordinate distorted by "white noise" under the additional assumption of the uniqueness of its extremum point and convexity upward.
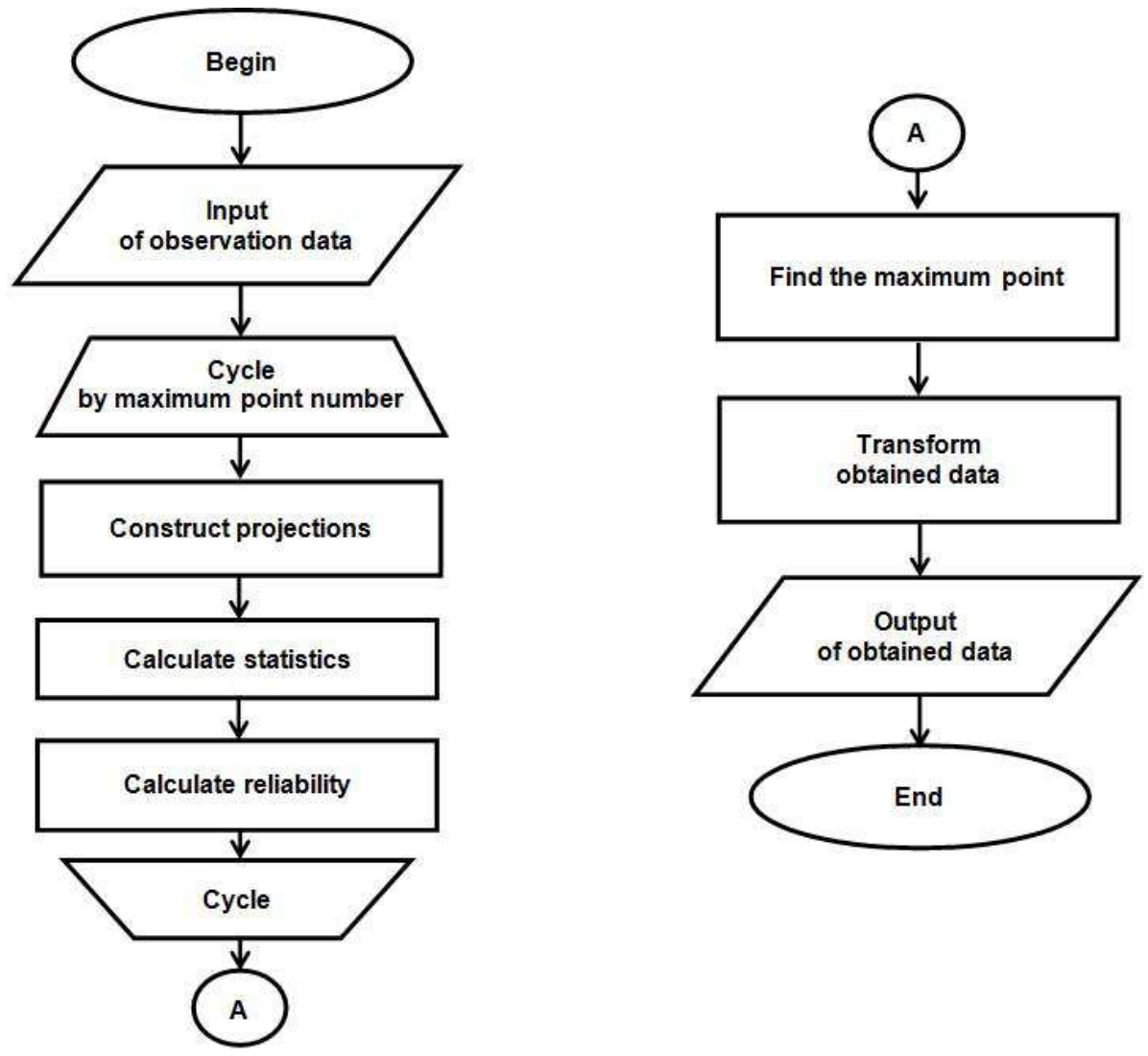

Fig. 1. Algorithm of the Pyt'ev-Chulichkov method

Let us describe the steps of this algorithm. As input data, we take the length of the time segment $\tau$, the number $N$ of discretization intervals, the values $\left\{\eta^{i}\left(t_{j}\right)\right\}_{j=0}^{N}$ distorted by "white noise" and the confidence probability $\gamma$ of finding the maximum point.

Let $k \in \mathcal{I}$ be a number of the uniform grid point in which the useful part of the signal $\widetilde{y}_{i}(t)$ has a maximum, i.e. $\widetilde{y}_{i} \in V_{k}$. We set $k=1$.

Step 1. Construct $P_{k}\left(\eta^{i}(t) \sqrt{t}\right)$, i.e. a projection of $\eta^{i}(t) \sqrt{t}$ onto the set $V_{k}$, by the algorithm described in [17].

Step 2. Calculate statistics (10).

Step 3. Calculate the reliability $\alpha(k)=\int p_{N(0, \sigma)}(x) d x$.

$$
\tau_{k}(x) \geq \tau_{k}(i)
$$

Since the value of $\alpha$ does not depend on $\sigma>0$, then the value can be found by the Monte-Carlo method by playing realizations of $N+1$ normally distributed random variables $x_{k} \sim N(0,1)$ and counting the frequency of realizations for which $\tau_{k}(x) \geq \tau_{k}(i)$. 
Step 4. Increase $k$ and if $k>N$, then go to Step 5, otherwise go to Step 1.

Step 5. Determine all values of $k$ for which $\alpha(k) \geq \gamma$ and consider the required $k_{0}$ to be the average value among these values of $k$.

Step 6. Calculate the values of the useful part of the observation $\widetilde{y}_{i}\left(t_{j}\right)$. Note that the previous steps allow to use the coordinates of the experiment data $\eta^{i}(t) \sqrt{t}$ in order to find the values $\widetilde{y}_{i}\left(t_{j}\right) \sqrt{t_{j}}$ and the position of the maximum point $\widetilde{y}_{i}(t) \sqrt{t}$, which is at the point $k_{0}$ with the probability $\gamma$. If the uniform grid $\left\{t_{j}\right\}_{j=0}^{N}$ contains the point $t=0$, then dividing by $\sqrt{t}$ may result in unreasonably large values. In order to avoid this, we remove this value together with the points of some neighborhood of this point from the array of values. The number of such points depends on the number $N$ of intervals of the grid and the length of the time interval $\tau$, on which problem $(1)-(5)$ is solved.

Using the described algorithm to each of the coordinates, we obtain the values of the observation vector function $\widetilde{y}(t)$, on the basis of which we search for a solution to optimal measurement problem $(1)-(5)$.

To illustrate how this algorithm works let's take the perturbed signal on the interval $(0 ; 2)$ and divide it into 200 parts, and get the parameters $\tau=2$ and $N=200$. Thus algorithm gives the values, the graphs of which are shown in Fig. 2. Fig. 3 shows graphs of the original and restored values.

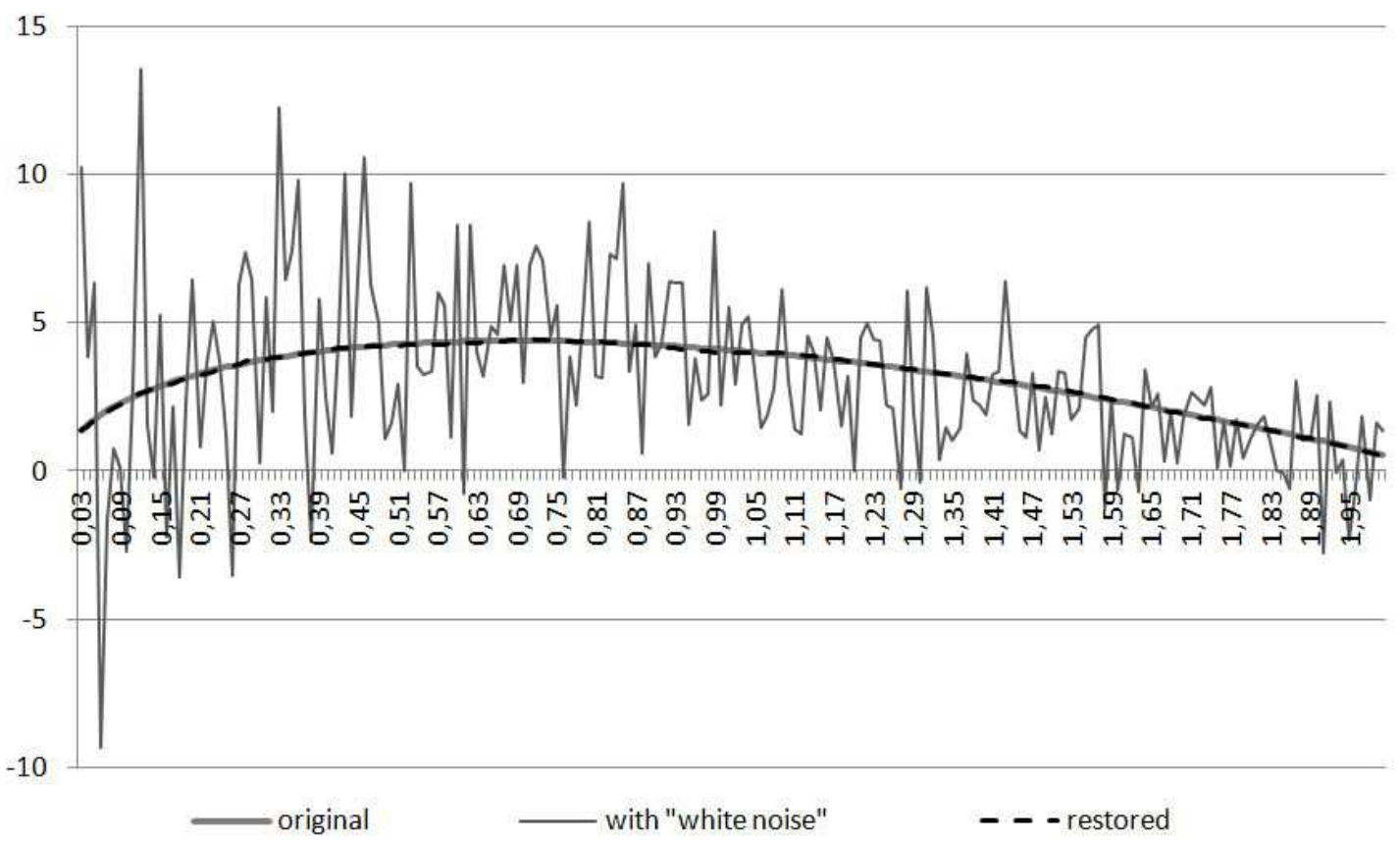

Fig. 2. Graphs of the original, noisy and restored components 


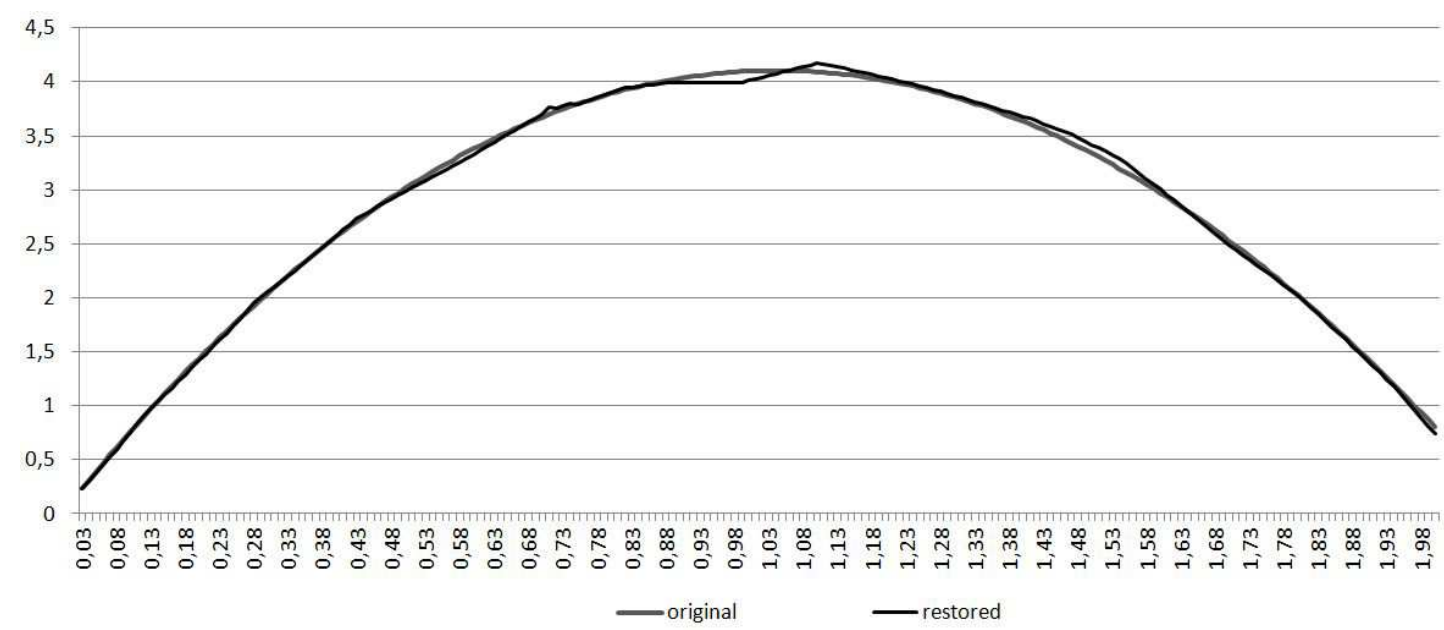

Fig. 3. Graphs of the original and restored signals

\section{Conclusion}

In the future, we intend to conduct computational experiments for constructing observation values from experimental data distorted by a multidimensional "white noise". In addition, the described procedure can be applied both to noises of another type and to other a priori information about the properties of the useful part of the signal.

Acknowledgements. This work was supported by the Ministry of Science and Higher Education of the Russian Federation (grant no. FENU-2020-0022 (2020072Г3)).

\section{References}

1. Granovskii V.A. Dinamicheskie izmereniya. Osnovy metrologicheskogo obespecheniya [Dynamic Measurements. Fundamentals of Metrology Provision]. Leningrad, Energoatomizdat, 1984. (in Russian)

2. Shestakov A.L. Metody teorii avtomaticheskogo upravleniya $v$ dinamicheskikh izmereniyakh [Methods of the Automatical Control Theory to Dynamical Measurements]. Chelyabinsk, Publishing center of SUSU, 2013. (in Russian)

3. Sviridyuk G.A., Efremov A.A. An Optimal Control Problem for a Class of Linear Degenerate Equations. Doklady Mathematics, 1999, vol. 59, no. 1, pp. 157-159.

4. Shestakov A.L., Sviridyuk G.A. A New Approach to Measurement of Dynamically Perturbed Signals. Bulletin of the South Ural State University. Series: Mathematical Modelling, Programming and Computer Software, 2010, no. 16 (192), issue 5, pp. 116-120.

5. Keller A.V. Numerical Solution of the Optimal Control Problem for Degenerate Linear System of Equations with Showalter-Sidorov Initial Conditions. Bulletin of the South Ural State University. Series: Mathematical Modelling, Programming and Computer Software, 2008, no. 27 (127), issue 2, pp. 50-56.

6. Shestakov A.L., Keller A.V., Nazarova E.I. Numerical Solution of the Optimal Measurement Problem. Automation and Remote Control, 2012, vol. 73, no. 1, pp. 97-104. DOI: $10.1134 /$ S0005117912010079 
7. Shestakov A.L., Sviridyuk G.A., Keller A.V. The Theory of Optimal Measurements. Journal of Computational and Engineering Mathematics, 2014, vol. 1, no. 1, pp. 3-15.

8. Shestakov A.L., Keller A.V., Zamyshlyaeva A.A., Manakova N.A., Zagrebina S.A., Sviridyuk G.A. The Optimal Measurements Theory as a New Paradigm in the Metrology. Journal of Computational and Engineering Mathematics, 2020, vol. 7, no. 1, pp. 3-23. DOI: $10.14529 /$ jcem200101

9. Keller A.V., Shestakov A.L., Sviridyuk G.A., Khudyakov Y.V. The Numerical Algorithms for the Measurement of the Deterministic and Stochastic Signals. Springer Proceedings in Mathematics and Statistics, vol. 113, 2015, pp. 183-195. DOI: 10.1007/978-3-319-12145-1_11

10. Sagadeeva M. On Nonstationary Optimal Measurement Problem for the Measuring Transducer Model. 2nd International Conference on Industrial Engineering, Applications and Manufacturing (ICIEAM-2016), Chelyabinsk, Russia, 2016, article ID: 7911710. DOI: $10.1109 /$ ICIEAM.2016.7911710

11. Keller A.V., Zagrebina S.A. Some Generalizations of the Showalter-Sidorov Problem for Sobolev-Type Models. Bulletin of the South Ural State University. Series: Mathematical Modelling, Programming and Computer Software, 2015, vol. 8, no. 2, pp. 5-23. DOI: $10.14529 / \mathrm{mmp150201}$ (in Russian)

12. Keller A.V., Sagadeeeva M.A. Degenerate Matrix Groups and Degenerate Matrix Flows in Solving the Optimal Control Problem for Dynamic Balance Models of the Economy. Springer Proceedings in Mathematics and Statistics, vol. 325, 2020, pp. 263-277. DOI: 10.1007/978-3030-46079-2_15

13. Pyt'ev Yu.P., Chulichkov A.I. Metody morfologicheskogo analiza izobrazheniy [Methods of Morphological Analysis of Pictures]. FizMatLit, Moscow, 2010. (in Russian)

14. Nelson E. Dynamical Theories of Brownian Motion. Princeton, Princeton University Press, 1967.

15. Gliklikh Yu.E. Global and Stochastic Analysis with Applications to Mathematical Physics. N.Y., Springer, 2011.

16. Gliklikh Yu.E., Zheltikova O.O. On Existence of Optimal Solutions for Stochastic Differential Inclusions with Mean Derivatives. Applicable Analysis, 2014, vol. 93, no. 1, pp. 35-45. DOI: $10.1080 / 00036811.2012 .753588$

17. Sagadeeva M.A. Reconstruction of Observation from Distorted Data for the Optimal Dynamic Measurement Problem. Bulletin of the South Ural State University. Series: Mathematical Modelling, Programming and Computer Software, 2019, vol. 12, no. 2, pp. 58-66. DOI: 10.14529/mmp190207 (in Russian)

18. Leontiev V. Ekonomicheskie esse. Teorii, issledovaniya, fakty, politika [Economic Essays. Theories, Research, Facts, Politics]. Moscow, Politizdat, 1990. (in Russian)

19. Boyarintsev Yu.E Lineynye $i$ nelineynye algebro-differentsial'nye sistemy [Linear and Nonlinear Algebra-Differential Systems]. Novosibirsk, Nauka, 2000. (in Russian)

20. März R. On Initial Value Problems in Differential-Algebraic Equations and Their Numerical Treatment. Computing, 1985, vol. 35, issue 1, pp. 13-37. DOI: 10.1007/BF02240144

21. Belov A.A., Kurdyukov A.P. Deskriptornye sistemy i zadachi upravleniya [Descriptor Systems and Control Problems]. Moscow, Fizmatlit, 2015. (in Russian)

22. Khudyakov Yu.V. On Mathematical Modeling of the Measurement Transducers. Journal of Computational and Engineering Mathematics, 2016, vol. 3, no. 3, pp. 68-73. DOI: $10.14529 /$ jcem160308 
23. Khudyakov Yu.V. On Adequacy of the Mathematical Model of the Optimal Dynamic Measurement. Journal of Computational and Engineering Mathematics, 2017, vol. 4, no. 2, pp. 14-25. DOI: $10.14529 /$ jcem170202

24. Einstein A., Smoluchowski M. Braunovskoe dvizhenie [Brownian Motion]. Moscow, Fizmatlit, 1936. (in Russian)

25. Demin D.S., Chulichkov A.I. Filtering of Monotonic Convex Noise-Distorted Signals and Estimates of Positions of Special Points. Fundamentalnaya i prikladnaya matematika, 2009, vol. 15, no. 6, pp. 15-31. (in Russian)

Received August 27, 2020

УДК 517.9

DOI: $10.14529 / \mathrm{mmp} 200407$

\title{
МЕТОД ПЫТЬЕВА - ЧУЛИЧКОВА ДЛЯ ПОСТРОЕНИЯ ИЗМЕРЕНИЯ В МОДЕЛИ ШЕСТАКОВА - СВИРИДЮКА
}

\author{
М.А. Сагадеева ${ }^{1}$, Е.В. Бычков ${ }^{1}$, О.Н. Цыпленкова \\ ${ }^{1}$ Южно-Уральский государственный университет, г. Челябинск, \\ Российская Федерация
}

\begin{abstract}
Одним из подходов решения задачи восстановления искаженного входного сигнала по регистрируемым выходным данным датчика является задача оптимального динамического измерения - модель Шестакова - Свиридюка. Эта модель является основой теории оптимальных динамических измерений и состоит из задачи минимизации разности значений виртуального наблюдения, полученного с помощью расчетной модели, и экспериментальных данных, обычно искаженных некоторыми помехами. В статье рассматривается модель Шестакова - Свиридюка оптимального динамического измерения при наличии помех разного вида. Основное внимание в статье обращено на предварительный этап исследования задачи оптимального динамического измерения, а именно на метод Пытьева - Чуличкова построения данных наблюдения, т.е. преобразования данных эксперимента для очистки их от помех в виде «белого шума», понимаемого как производная Нельсона - Гликлиха от многомерного винеровского процесса. Для использования этого метода используется априорная информация о свойствах функций, описывающих наблюдение.

Ключевые слова: оптимальное динамическое измерение; система леонтъевского типа; многомерный винеровский процесс; производная Нелъсона - Гликлиха; алгоритм решения задачи.
\end{abstract}

\section{Литература}

1. Грановский, В.А. Динамические измерения. Основы метрологического обеспечения / В.А. Грановский. - Л.: Энергоатомиздат, 1984. - 224 с.

2. Шестаков, А.Л. Методы теории автоматического управления в динамических измерениях / А.Л. Шестаков. - Челябинск: Издательский центр ЮУрГУ, 2013. - 257 с.

3. Свиридюк, Г.А. Оптимальное управление одним классом линейных вырожденных уравнений / Г.А. Свиридюк, А.А. Ефремов / Доклады Академии наук. - 1999. - Т. 346, № 3. C. $323-325$.

4. Шестаков, А.Л. Новый подход к измерению динамически искаженных сигналов / А.Л. Шестаков, Г.А. Свиридюк // Вестник ЮУрГУ. Серия: Математическое моделирование и программирование. - 2010. - № 16 (192). - С. 116-120. 
5. Келлер, А.В. Численное решение задачи оптимального управления вырожденной линейной системой уравнений с начальными условиями Шоуолтера - Сидорова / А.В. Келлер // Вестник ЮУрГУ. Серия: Математическое моделирование и программирование. 2008. - № 27, вып. 127. - С. 50-56.

6. Шестаков, А.Л. Численное решение задачи оптимального измерения / А.Л. Шестаков, А.В. Келлер, Е.И. Назарова // Автоматика и телемеханика. - 2012. - № 1. - С. 107-115.

7. Shestakov, A.L. Theory of Optimal Measurements / A.L. Shestakov, G.A. Sviridyuk, A.V. Keller // Journal of Computational and Engineering Mathematics. - 2014. - V. 1, № 1. - P. 3-15.

8. Shestakov, A.L. The Optimal Measurements Theory as a New Paradigm in the Metrology / A.L. Shestakov, A.V. Keller, A.A. Zamyshlyaeva, N.A. Manakova, S.A. Zagrebina, G.A. Sviridyuk // Journal of Computational and Engineering Mathematics. - 2020. - V. 7, № 1. - P. 3-23.

9. Keller, A.V. The Numerical Algorithms for the Measurement of the Deterministic and Stochastic Signals / A.V. Keller, A.L. Shestakov, G.A. Sviridyuk, Y.V. Khudyakov // Springer Proceedings in Mathematics and Statistics. - V. 113. - 2015. - P. 183-195.

10. Sagadeeva, M. On Nonstationary Optimal Measurement Problem for the Measuring Transducer Model / M. Sagadeeva // 2nd International Conference on Industrial Engineering, Applications and Manufacturing (ICIEAM-2016), Chelyabinsk, Russia. 2016. - A/N 7911710.

11. Келлер, А.В. Некоторые обобщения задачи Шоуолтера - Сидорова для моделей соболевского типа / А.В. Келлер, С.А. Загребина // Вестник ЮУрГУ. Серия: Математическое моделирование и программирование. - 2015. - Т. 8, № 2. - С. 5-23.

12. Keller, A.V. Degenerate Matrix Groups and Degenerate Matrix Flows in Solving the Optimal Control Problem for Dynamic Balance Models of the Economy / A.V. Keller, M.A. Sagadeeeva // Springer Proceedings in Mathematics and Statistics. - V. 325. - 2020. P. 263-277.

13. Пытьев, Ю.П. Методы морфологического анализа изображений / Ю.П. Пытьев, А.И. Чуличков. - М.: Физматлит, 2010.

14. Nelson, E. Dynamical Theories of Brownian Motion / E. Nelson. - Princeton: Princeton University Press, 1967.

15. Gliklikh, Yu.E. Global and Stochastic Analysis with Applications to Mathematical Physics / Yu.E. Gliklikh. - London; Dordrecht; Heidelberg; N.Y.: Springer, 2011.

16. Gliklikh, Yu.E. On Existence of Optimal Solutions for Stochastic Differential Inclusions with Mean Derivatives / Yu.E. Gliklikh, O.O. Zheltikova // Applicable Analysis. - 2014. V. 93, № 1. - P. 35-45.

17. Сагадеева, М.А. Алгоритм восстановления измерения по наблюдению, возмущенному «белым шумом» / М.А. Сагадеева // Вестник ЮУрГУ. Серия: Математическое моделирование и программирование. - 2019. - Т. 12, № 2. - С. 58-66.

18. Леонтьев, В. Экономические эссе. Теории, исследования, факты, политика / В. Леонтьев. - М.: Политиздат, 1990.

19. Бояринцев, Ю.Е. Линейные и нелинейные алгебро-дифференциальные системы / Ю.Е. Бояринцев. - Новосибирск: Наука, 2000.

20. März, R. On Initial Value Problems in Differential-Algebraic Equations and Their Numerical Treatment / R. März // Computing. - 1985. - V. 35, issue 1. - P. 13-37. 
21. Белов, А.А. Дескрипторные системы и задачи управления / А.А. Белов, А.П. Курдюков. - М.: Физматлит, 2015.

22. Khudyakov, Yu.V. On Mathematical Modeling of the Measurement Transducers / Yu.V. Khudyakov // Journal of Computational and Engineering Mathematics. - 2016. - V. 3, № 3. - P. 68-73.

23. Khudyakov, Yu.V. On Adequacy of the Mathematical Model of the Optimal Dynamic Measurement / Yu.V. Khudyakov // Journal of Computational and Engineering Mathematics. - 2017. - V. 4, № 2. - P. 14-25.

24. Эйнштейн, А. Брауновское движение / А. Эйнштейн, М. Смолуховский. - М.: Физматлит, 1936.

25. Демин, Д.С. Фильтрация монотонных выпуклых сигналов, искаженных шумом, и оценка положения особых точек / Д.С. Демин, А.И. Чуличков // Фундаментальная и прикладная математика. - 2009. - Т. 15, № 6. - С. 15-31.

Минзиля Алмасовна Сагадеева, кандидат физико-математических наук, доцент, кафедра математического и компьютерного моделирования, Южно-Уральский государственный университет (Челябинск, Российская Федерация), sagadeevama@susu.ru.

Евгений Викторович Бычков, кандидат физико-математических наук, доцент, кафедра уравнений математической физики, Южно-Уральский государственный университет (Челябинск, Российская Федерация), bychkovev@susu.ru.

Ольга Николаевна Цыпленкова, кандидат физико-математических наук, доцент, кафедра уравнений математической физики, Южно-Уральский государственный университет (Челябинск, Российская Федерация), tsyplenkovaon@susu.ru.

Поступила в редакиию 27 августа 2020 г. 